\section{IJ§ER}

ISSN: 2149-5939
International Journal of Social Sciences and Education Research

Online, http://dergipark.gov.tr/ijsser

Volume: $2(2), 2016$

\title{
Adapting WIOD tables to national IO Tables for Turkey
}

\author{
Meral Özhan ${ }^{1}$
}

Received Date: 12 / $10 / 2015$

Accepted Date: 01 / $01 / 2016$

\begin{abstract}
This paper presents the adjustment process of the WIOD (World Input-Output Database) tables of Turkey to national accounts data coming from the TurkStat (Turkish Statistical Institute). The database covers 27 EU countries and 13 other major countries in the world for the period 1995 to 2011. The main aim of the paper is to construct a series of balanced input-output tables (IOTs) for Turkey's Interindustry Analysis Model (Turina). TURINA is an Interdyme type (Interindustry dynamic macroeconomic) model developed by INFORUM (Interindustry Forecasting at University of Maryland). The Inforum model requires one or more IO tables with three blocks: i. Total intermediate (domestic plus import) interindustry flow matrix, FM ii. Final demand block, FD, iii. And Value added block, VA. A time series of 35-sector annual IO tables for the Turkish economy has been constructed by the WIOD. The format of national input-output tables in WIOD is different from the normal format of national inputoutput tables which can be directly used in building an INFORUM model. The WIOD structure consists of six blocks: i. Intermediate flow matrix which only shows domestically produced inputs. ii. Final demand goods produced by domestic industries. iii. An import matrix which shows import components of intermediate inputs into domestic industries. iv. Imports components of final demand categories. v. Value added block at the bottom rows of the whole table. vi. Some elements of value added rows inside the final demand block. In the adjustment process three major steps are taken. The first step requires the addition of import rows to domestic rows in order to obtain the total intermediate and final demand figures. The second step requires the adjustment of the sum of final demand categories to national account totals at aggregate level. The third step requires the adjustment of value added totals to national account income figures provided by national statistical office. After all these steps any imbalances which are almost always the case an RAS procedure is applied to balance the whole system at sectoral level. At the present stage I have checked the WIOD table for 2011. Starting from the final demand side, I observed that there are no deviations for Government expenditures and Gross domestic fixed investment between the WIOD and the TurkStat figures. For other variables of final demand block (Consumption, Changes in stocks, Exports, Imports,) some slight differences were observed. Therefore initially, the GDP figure in the TurkStat sources exceeded the WIOD figure by 3.2 percent. Finally, with a series of balancing adjustments both at macro and sectoral level the WIOD table for 2011 is made consistent with the TurkStat data.

Keywords: Balancing input-output tables, Interindustry macroeconomic model for Turkey, Database for multisectoral models
\end{abstract}

\section{Introduction}

In April 2012, the WIOD (World Input-Output Database) started to publish a series of 35sector annual IOTs (Input-Output Tables) for $27 \mathrm{EU}$ economies and 13 other major world economies (including Turkey) over the period of 1995 to 2009 out of a project funded by the European Commission. In 2014 WIOD (www.wiod.org) added two new annual tables for 2010 and 2011. In addition to IOTs the database also provides some additional macroeconomic aggregate figures in the form of socio-economic accounts (SEA). The general structure of these IOTs is given in Table 1 for 2011 with actual values.

\footnotetext{
${ }^{1}$ Assoc. Prof. Dr. Hacettepe University, ANKARA/TURKEY, ozhan@hacettepe.edu.tr; ozhan.meral@gmail.com
} 
Özhan, M. (2016). Adapting WIOD tables to national IO Tables for Turkey. International Journal of Social Sciences and Education Research, 2 (2), 327-337.

Table 1. Input-Output Table for 2011, by WIOD in current prices, (industry-by-industry), (millions of US\$)

\begin{tabular}{|c|c|c|c|c|c|c|c|c|c|}
\hline & 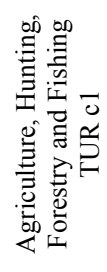 & & 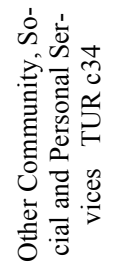 & 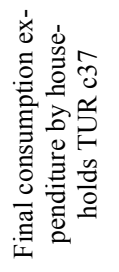 & 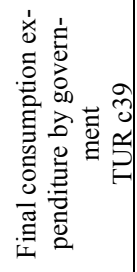 & 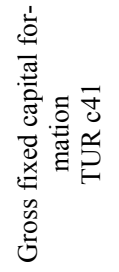 & 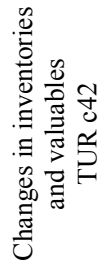 & 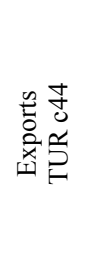 & 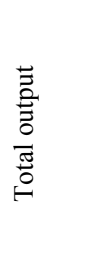 \\
\hline $\begin{array}{l}\text { Agriculture, Hunting, } \\
\text { Forestry and Fishing } \\
\text { TUR c1 }\end{array}$ & 11,610 & & 29 & 39,228 & 359 & 86 & 1,579 & 6,321 & 98,682 \\
\hline & & & $\ldots$ & $\ldots$ & & $\ldots$ & $\ldots$ & $\ldots$ & $\ldots$ \\
\hline $\begin{array}{l}\text { Other Community, Social } \\
\text { and Personal Services } \\
\text { TUR c34 }\end{array}$ & 41 & $\cdot$ & 2,990 & 12,015 & 3,805 & 158 & 6 & 402 & 23,591 \\
\hline $\begin{array}{l}\text { Agriculture, Hunting, } \\
\text { Forestry and Fishing Imp } \\
\text { c1 }\end{array}$ & 1,439 & & 3 & 5,836 & 29 & 16 & 0 & 0 & 12,594 \\
\hline & $\ldots$ & & $\ldots$ & & & $\ldots$ & & .. & $\ldots$ \\
\hline $\begin{array}{l}\text { Other Community, Social } \\
\text { and Personal Services } \\
\text { Imp c34 }\end{array}$ & 1 & & 154 & 192 & 91 & 4 & 0 & 0 & 697 \\
\hline $\begin{array}{l}\text { Total intermediate con- } \\
\text { sumption TOT r60 }\end{array}$ & 32,607 & & 10,334 & 442,057 & 105,714 & 162,765 & 14,054 & 0 & 0 \\
\hline $\begin{array}{l}\text { Taxes less subsidies on } \\
\text { products r99 }\end{array}$ & 3,748 & & 544 & 40,522 & 2,304 & 5,018 & 929 & 0 & 0 \\
\hline $\begin{array}{l}\text { Cif/ fob adjustments on } \\
\text { exports r61 }\end{array}$ & 0 & 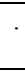 & 0 & 0 & 0 & 0 & 0 & 0 & 0 \\
\hline $\begin{array}{l}\text { Direct purchases abroad } \\
\text { by residents } \mathrm{r} 62\end{array}$ & & & 0 & 5,007 & 0 & 0 & 0 & 0 & 0 \\
\hline $\begin{array}{l}\text { Purchases on the domes- } \\
\text { tic territory by non-resi- } \\
\text { dents r63 }\end{array}$ & 0 & & 0 & $-27,941$ & 0 & 0 & 0 & 0 & 0 \\
\hline $\begin{array}{l}\text { Value added at basic } \\
\text { prices r64 }\end{array}$ & 62,094 & & 17,694 & 0 & 0 & 0 & 0 & 0 & 0 \\
\hline $\begin{array}{l}\text { International Transport } \\
\text { Margins }\end{array}$ & 233 & & 19 & 7,445 & 376 & 2,101 & 0 & 0 & 0 \\
\hline Output at basic prices r69 & 98,682 & & 23,591 & 0 & 0 & 0 & 0 & 0 & 0 \\
\hline
\end{tabular}

The aim of this paper is to produce, out of this rich data source, for our Turkish interindustry macroeconomic analysis model (TURINA) a set of well-balanced IOT series consistent with the national accounts statistics (NAS). The WIOD data for Turkey within the TURINA framework was also employed by the professional model builders at GWS (Großmann, Hohmann, Wiebe, 2012). Since the TurkStat has not published any further IOT since 2002, the rational choice is to make use of the WIOD data available free of charge. However, the format of the WIOD tables are different from the normal structure of the IOT applied by the INFORUM which is shown in Table 2. INFORUM models are of interindustry dynamic macroeconomic models which is known as Interdyme. Since TURINA is a special form of INFORUM model it is necessary to convert and adjust the WIOD tables to the one adapted by INFORUM. 
Özhan, M. (2016). Adapting WIOD tables to national IO Tables for Turkey. International Journal of Social Sciences and Education Research, 2 (2), 327-337.

Table 2. Input-output table adapted by inforum (for an Imaginary Economy)

\begin{tabular}{|c|c|c|c|c|c|c|c|c|c|c|}
\hline & 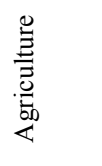 & $\begin{array}{l}\overrightarrow{\vec{E}} \\
\stackrel{\vec{E}}{\Xi} \\
\vec{\Xi}\end{array}$ & 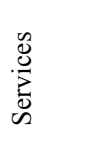 & 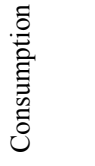 & 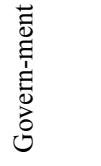 & 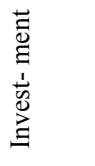 & 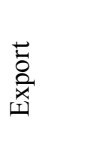 & $\begin{array}{l}\text { : } \\
\text { :्ञ } \\
\text {. }\end{array}$ & 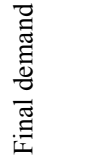 & 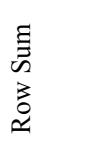 \\
\hline Agriculture & 15 & 25 & 40 & 80 & 15 & 5 & 85 & -15 & 170 & 250 \\
\hline Industry & 40 & 60 & 80 & 150 & 25 & 60 & 60 & -75 & 220 & 400 \\
\hline Services & 80 & 90 & 100 & 200 & 40 & 30 & 40 & -30 & 280 & 550 \\
\hline Intermediate & 135 & 175 & 220 & & & & & & & 530 \\
\hline Depreciation & 10 & 20 & 25 & & & & & & & 55 \\
\hline Labour & 65 & 100 & 170 & & & & & & & 335 \\
\hline Capital & 30 & 75 & 90 & & & & & & & 195 \\
\hline Indirect tax & 10 & 30 & 45 & & & & & & & 85 \\
\hline Value added & 115 & 225 & 330 & & & & & & & 670 \\
\hline Column Sum & 250 & 400 & 550 & 430 & 80 & 95 & 185 & -120 & 670 & \\
\hline
\end{tabular}

Note: Numbers are author`s calculations. Format is adapted from Almon (2011).

The WIOD IOT structure consists of six blocks: i. Intermediate flow matrix which only shows domestically produced inputs. ii. Final demand goods produced by domestic industries. iii. An import matrix which shows import components of intermediate inputs into domestic industries. iv. Imports components of final demand categories. v. value added block at the bottom rows of the whole table. vi. Some elements of value added rows into final demand block. On the other hand the format of the IOT by INFORUM has only three blocks: i. Interindustry flow matrix, FM, which contains both domestic and imported intermediary inputs; ii. Final demand block, FD placed to the right of FM; iii. Value added block, VA, placed at the bottom of FM. In this form the fourth possible block which can be placed at the right corner of the whole table is left blank. In Miller and Blair (2013) this blank block designated as the region of GDP.

The remaining sections of the paper are designed as follows. The next section introduces the relationship between IOT and NAS statistics. Section three describes the conversion and adjustment process of the WIOD tables to INFORUM structure at macro level. It also introduces the IO model briefly. In the fourth section the process converting the macro balance into sectoral detail is explained. The final section concludes.

\section{Input-output tables, national accounts and the IO model}

One of the properties or benefits of an input-output table such as the one given in Table 2 is to calculate the basic elements of national accounts. The first one is GDP figure for a national economy. There are three approaches to measure GDP. The first is the expenditure or net output approach. Using this approach within the framework of an IO table GDP is measured as the sum of all final demand elements. In Table 2 let $\mathrm{f}_{1}, \mathrm{f}_{2}, \mathrm{f}_{3}$ show the row totals of final demand vectors for three sectors respectively. Therefore

$f_{i}=c_{i}+g_{i}+i_{i}+x_{i}-m_{i} \quad i=1, \ldots, 3$

where,

$\mathrm{c}_{\mathrm{i}}=$ Personal consumption expenditure supplied by sector $\mathrm{i}$ 
Özhan, M. (2016). Adapting WIOD tables to national IO Tables for Turkey. International Journal of Social Sciences and Education Research, 2 (2), 327-337.

$$
\begin{aligned}
& \mathrm{g}_{\mathrm{i}}=\text { Government consumption expenditure } \\
& \mathrm{i}_{\mathrm{i}}=\text { Gross fixed capital formation (including changes in stocks) } \\
& \mathrm{x}_{\mathrm{i}}=\text { Exports } \\
& \mathrm{m}_{\mathrm{i}}=\text { Imports }
\end{aligned}
$$

The sum of all final demand goods supplied by three production sectors gives GDP by the expenditure approach. Hence

$$
G D P=\sum_{i=1}^{3} f_{i}=\sum_{i=1}^{3} c_{i}+\sum_{i=1}^{3} g_{i}+\sum_{i=1}^{3} i_{i}+\sum_{i=1}^{3} x_{i}-\sum_{i=1}^{3} m_{i}
$$

Or

$$
G D P=C+G+I+X-M
$$

where,

$\mathrm{C}=$ Total consumption by all consumers in all three sectors

$\mathrm{G}=$ Total government expenditures in all three sectors

$\mathrm{I}=$ Total capital goods produced by all three sectors

$\mathrm{X}=$ Total exports

$M=$ Total imports

Therefore with a balanced IOT it is easier to calculate the GDP figures with its main aggregate (macro) components. By applying Equation (3) and using the illustrative numbers for the imaginary economy represented in Table 2 the GDP figure is calculated as follows.

$$
\mathrm{GDP}=430+80+95+185-120=670
$$

The second method of measuring GDP is the income approach. This method uses the sum of all primary income payments to calculate GDP. Accordingly, from Table 2, GDP is the sum of four income categories paid by all three sectors.

$$
G D P=D+L+K+T
$$

where,

D: Depreciation allowance by all three sectors

L: Labour income paid by all three sectors

$\mathrm{K}$ : Capital income (all non-wage income)

$\mathrm{T}$ : Net indirect business taxes (taxes minus subsidies)

By applying Equation (4) and again using the numbers for the same imaginary economy represented in Table 2, the GDP figure is calculated as follows

$$
\mathrm{GDP}=55+335+195+85=670
$$

The third method of measuring or estimating GDP is known as the production approach. It measures GDP in way to find value added generated by each sector of the economy by subtracting 
Özhan, M. (2016). Adapting WIOD tables to national IO Tables for Turkey. International Journal of Social

Sciences and Education Research, 2 (2), 327-337.

all intermediate cost of production from the total sectoral output. Therefore IOT is an ideal framework to find the income and the GDP in an economy in an indirect way. The process in this method is as follows.

Let $v_{i}$ show the value added generated in sector $i, q_{i}$ show the total output in the same sector. For the three-sector economy shown in Table 2 the amount (value) of intermediate input from sector $\mathrm{i}$ to sector $\mathrm{j}$ is given by $\mathrm{x}_{\mathrm{ij}}$. Thus, the value added in sector $\mathrm{j}$ is

$$
v_{j}=q_{j}-\sum_{i=1}^{3} x_{i j}
$$

Then, it follows that the GDP by the production approach is

$$
G D P=\sum_{j=1}^{3} v_{j}
$$

Applying Equation (6) and using the numbers for the same imaginary economy represented in Table 2, the GDP figure by this approach is calculated as follows

$$
G D P=115+225+330=670
$$

Since there is only one GDP figure for every economy the three methods should provide the same figure. In our representative three-sector economy this figure is 670 .

Finally, it would be informative to notice that the Turkish Statistical Institute (TurkStat) applies only two methods to calculate the GDP of Turkey: Production approach and expenditure approach. The institute also applied the income approach in the past but only for a brief period, from 1987 to 2006 .

In order to appreciate the role of a series of well-balanced annual IOTs consistent with the basic macroeconomic time series data, a brief introduction to the IO model will be useful.

The core of a multisectoral macroeconomic model is a square matrix of input-output coefficients denoted as A. A typical element of A is defined by

$$
a_{i j}=\frac{x_{i j}}{q_{j}}
$$

For example, from Table 2,

$$
a_{23}=\frac{x_{23}}{q_{3}}=\frac{80}{550}=0.145 \text {. }
$$

Accordingly, for the three-sector economy the technology matrix A is calculated as follows.

$A=\left[\begin{array}{lll}a_{11} & a_{12} & a_{13} \\ a_{21} & a_{22} & a_{23} \\ a_{31} & a_{32} & a_{33}\end{array}\right]=\left[\begin{array}{lll}0.060 & 0.063 & 0.073 \\ 0.160 & 0.150 & 0.145 \\ 0.320 & 0.225 & 0.182\end{array}\right]$

Given the technology matrix A the IO production model is given by

$$
q=A q+f
$$

where,

$q=$ column vector of sectoral output totals obtained by summing the rows of the IO table

$\mathrm{f}=$ vector of final demand totals obtained by summing the rows of the FD block

The solution of the IO model is given by

$q=[I-A]^{-1} f$ 
Özhan, M. (2016). Adapting WIOD tables to national IO Tables for Turkey. International Journal of Social Sciences and Education Research, 2 (2), 327-337.

In Equation (10), $[I-A]^{-1}$ is known as the Leontief inverse. However in INFORUM models the Leontief inverse is seldom used (Almon, 2011). Instead an iterative approach is applied to find the output vector for every year of the historical as well as the forecast period of a dynamic multisectoral model. To secure the convergence of the iterative process consistent with the results of all other complementary macroeconomic equations and regressions in the model, IOTs should be balanced explicitly or implicitly for every year. Briefly, without a balanced IOT table for every year a multisectoral macroeconomic model will never converge, i.e., there will be no solution.

Multisectoral macroeconomic models are also called "structural" macroeconomic models. The term "structural" indicates that not only macro-economic key variables such as GDP and its components on the demand and supply side are modelled, but that the sectoral structure of the economy is represented as well (Stover, Wiebe, Lehr, 2013).

\section{Adjustment at macro level}

The aim of macroeconomic adjustment is, without loss of any information, to eliminate the figures at the GDP block of the WIOD IOT so that the resulting form should be identical with the form adopted by INFORUM. Furthermore in the final stage of this process all of the macro variables of the GDP by the expenditure approach, C, G, I, S, X, and M must be identical with those statistics published by the TurkStat. During the macro adjustment process three steps are taken.

Step 1. i. Add the intermediate import flow matrix to domestic flow matrix. The latter starts with imp c1 and ends with imp c35 in Table1. Note that both TUR c35 row (and column) and Imp 35 row are missing in Table 1 as they do not contain any intermediate inputs. Also dd the import flows to final demand items to domestic final demand cells. The result will be a four-block IOT.

ii. Ignore Cif/fob adjustment row since it has all zeros in every cell.

iii. In the VA block add, the "Taxes less subsidies on product" row to the "Value added at basic prices" row and call this last new row as "Value added at market prices".

iii. Convert dollar values to TL. For 2011 from the SEA data of WIOD I found the implicit exchange rate TL1.6668 per dollar. This rate is also checked with the local data sources from TurkStat and MoD (Ministry of Development). It is found that, $\$ 1=$ TL1.7 in these last two sources.

The result of the first step at macro level is shown in Table 3.

At the end of the first step, the difference for the Consumption figure between the WIOD sources and the TurkStat data is only 3,042 million, which is about 0.3 percent. For Government and Investment there is no difference between the two sources. For the remaining three items of the FD block the deviations are relatively significant: For Stocks, it is 2,528 (11.2\%), for Exports it is -49,426 ($15.9 \%)$, and for Imports it is $-8,934(-2.1 \%)$. As a result, the GDP figure in the WIOD sources appeared 41,044 (3.2\%) less than the GDP in the TurkStat sources.

Step 2. After the completion of Step 1 there are now only four blocks, the last one is shown in Table 3 below. Inside the fourth block there are some numbers at the intersection of the row of "Taxes less subsidies on products" with the columns of Consumption, Government, Investment, and Stocks. Also at the bottom of Consumption column there are two non-zero entries: 8,346 in the row "Direct purchases abroad by residents", and $-44,673$ in the row "Purchases on the domestic territory by non-residents". Two adjustments had to be made.

i. Add 8,346 to Import column. 
Özhan, M. (2016). Adapting WIOD tables to national IO Tables for Turkey. International Journal of Social

Sciences and Education Research, 2 (2), 327-337.

ii. Add 44,673 to Export column.

iii. Still these two numbers are kept in the original consumption column.

Table 3. Adjustment at Macro Level, Step 1

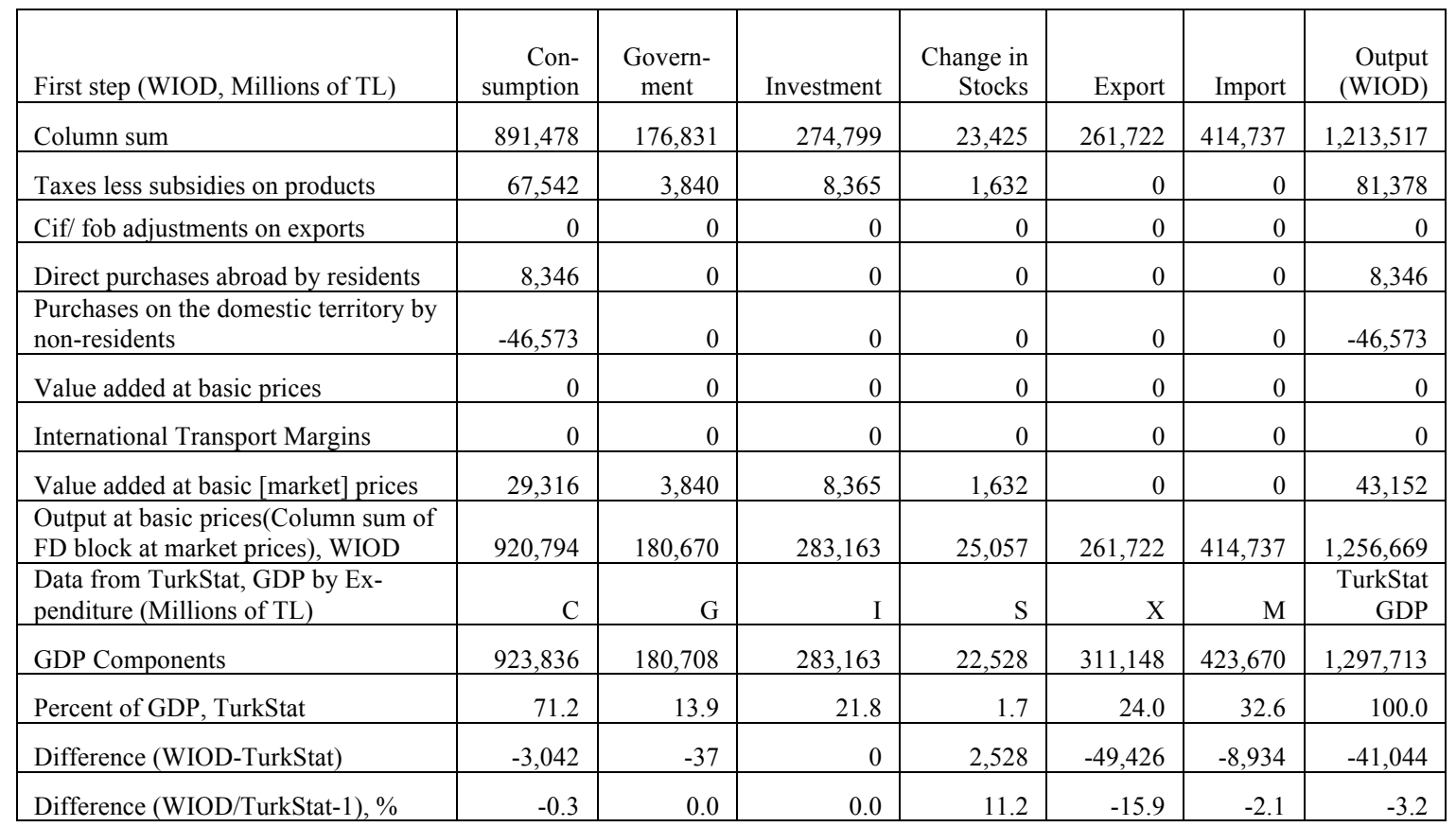

The resulting balance at the end of second step is given in Table 4 .

Table 4. Adjustment at macro level, step 2

\begin{tabular}{|c|c|c|c|c|c|c|c|}
\hline $\begin{array}{l}\text { Second step (WIOD, Millions } \\
\text { of TL) }\end{array}$ & $\begin{array}{r}\text { Consump- } \\
\text { tion }\end{array}$ & $\begin{array}{l}\text { Govern- } \\
\text { ment }\end{array}$ & Investment & $\begin{array}{r}\text { Change in } \\
\text { Stocks }\end{array}$ & Export & Import & $\begin{array}{r}\text { Output } \\
\text { (WIOD) }\end{array}$ \\
\hline Column sum & 891,478 & 176,831 & 274,799 & 23,425 & 261,722 & 414,737 & $1,213,517$ \\
\hline $\begin{array}{l}\text { Taxes less subsidies on prod- } \\
\text { ucts }\end{array}$ & 67,542 & 3,840 & 8,365 & 1,632 & 0 & 0 & 81,378 \\
\hline $\begin{array}{l}\text { Cif/ fob adjustments on ex- } \\
\text { ports }\end{array}$ & 0 & 0 & 0 & 0 & 0 & 0 & 0 \\
\hline $\begin{array}{l}\text { Direct purchases abroad by } \\
\text { residents }\end{array}$ & 8,346 & 0 & 0 & 0 & 0 & 8,346 & 0 \\
\hline $\begin{array}{l}\text { Purchases on the domestic } \\
\text { territory by non-residents }\end{array}$ & $-46,573$ & 0 & 0 & 0 & 46,573 & 0 & 0 \\
\hline Value added at basic prices & 0 & 0 & 0 & 0 & 0 & 0 & 0 \\
\hline $\begin{array}{l}\text { International Transport Mar- } \\
\text { gins }\end{array}$ & 0 & 0 & 0 & 0 & 0 & 0 & 0 \\
\hline $\begin{array}{l}\text { Value added at basic[market] } \\
\text { prices }\end{array}$ & 29,316 & 3,840 & 8,365 & 1,632 & 46,573 & 8,346 & 81,379 \\
\hline $\begin{array}{l}\text { Output at basic prices (Col- } \\
\text { umn sum of FD block at mar- } \\
\text { ket prices), WIOD }\end{array}$ & 920,794 & 180,670 & 283,163 & 25,057 & 308,295 & 423,083 & $1,294,896$ \\
\hline $\begin{array}{l}\text { Data from TurkStat, GDP by } \\
\text { Expenditure (Millions of TL) }\end{array}$ & $\mathrm{C}$ & $\mathrm{G}$ & I & $\mathrm{S}$ & $\mathrm{X}$ & M & $\begin{array}{r}\text { TurkStat } \\
\text { GDP }\end{array}$ \\
\hline GDP Components & 923,836 & 180,708 & 283,163 & 22,528 & 311,148 & 423,670 & $1,297,713$ \\
\hline Percent of GDP, TurkStat & 71.2 & 13.9 & 21.8 & 1.7 & 24.0 & 32.6 & 100.0 \\
\hline Difference (WIOD-TurkStat) & $-3,042$ & -37 & 0 & 2,528 & $-2,853$ & -588 & $-2,817$ \\
\hline $\begin{array}{l}\text { Difference (WIOD/TurkStat- } \\
1), \%\end{array}$ & -0.3 & 0.0 & 0.0 & 11.2 & -0.9 & -0.1 & -0.2 \\
\hline
\end{tabular}


Özhan, M. (2016). Adapting WIOD tables to national IO Tables for Turkey. International Journal of Social Sciences and Education Research, 2 (2), 327-337.

At the end of Step 2, there is a negligible difference (-0.2\%) between the two GDP values coming from WIOD and TurkStat respectively. The only significant difference appeared in the "Change in Stocks" column (11.2\%).

Step 3. After the sectoral adjustment which will be explained in Section 4, it was easy to eliminate the remaining difference in Stocks. In the process of sectoral adjustment any remaining differences are eliminated by necessary changes either in the total output vector or the changes in stocks. In the TurkStat sources there are no corresponding figures for output levels in any sector or at macro level. For that reason it was easy to change sectoral output levels in macro or sectoral adjustment process. Briefly, I left the sectoral total output figure to be residually determined and vary the figures in the changes in Stocks column freely.

Table 5. Adjustment at Macro Level, Step 3

\begin{tabular}{|c|c|c|c|c|c|c|c|}
\hline $\begin{array}{c}\text { Final step (WIOD, Millions } \\
\text { of TL) }\end{array}$ & Consumption & $\begin{array}{l}\text { Govern- } \\
\text { ment }\end{array}$ & Investment & $\begin{array}{l}\text { Change in } \\
\text { Stocks }\end{array}$ & Export & Import & $\begin{array}{c}\text { Output } \\
\text { (WIOD) }\end{array}$ \\
\hline Column sum & 923,837 & 180,707 & 283,163 & 22,529 & 311,148 & 423,671 & $1,297,713$ \\
\hline \multicolumn{8}{|l|}{ Taxes less subsidies on } \\
\hline \multicolumn{8}{|l|}{ Cif/ fob adjustments on ex- } \\
\hline \multicolumn{8}{|l|}{ Direct purchases abroad by } \\
\hline \multicolumn{8}{|l|}{$\begin{array}{l}\text { Purchases on the domestic } \\
\text { territory by non-residents }\end{array}$} \\
\hline \multicolumn{8}{|l|}{ Value added at basic prices } \\
\hline \multicolumn{8}{|l|}{ International Transport Mar- } \\
\hline \multicolumn{8}{|l|}{ Value added at basic [mar- } \\
\hline $\begin{array}{l}\text { Output at basic prices (Col- } \\
\text { umn sum of FD block at } \\
\text { market prices), WIOD }\end{array}$ & 923,837 & 180,707 & 283,163 & 22,529 & 311,148 & 423,671 & $1,297,713$ \\
\hline $\begin{array}{l}\text { Data from TurkStat, GDP } \\
\text { by Expenditure (Millions of }\end{array}$ & $\mathrm{C}$ & $\mathrm{G}$ & I & $\mathrm{S}$ & $\mathrm{X}$ & M & $\begin{array}{r}\text { TutkStat } \\
\text { GDP }\end{array}$ \\
\hline GDP Components & 923,836 & 180,708 & 283,163 & 22,528 & 311,148 & 423,670 & $1,297,713$ \\
\hline Percent of GDP, TurkStat & 71.2 & 13.9 & 21.8 & 1.7 & 24.0 & 32.6 & 100.0 \\
\hline $\begin{array}{l}\text { Difference (WIOD-Turk- } \\
\text { Stat) }\end{array}$ & 0.0 & -0.4 & 0.3 & 0.3 & -0.2 & 0.5 & -0.1 \\
\hline $\begin{array}{l}\text { Difference (WIOD/Turk- } \\
\text { Stat-1), \% }\end{array}$ & 0.0 & 0.0 & 0.0 & 0.0 & 0.0 & 0.0 & 0.0 \\
\hline
\end{tabular}

Finally, the resulting IO table balanced at macro level is shown in Table 5. All imbalances are eliminated and the error for each of the macro variables (C, G, I, S, X and M) in the GDP by expenditure method is now zero.

\section{Adjustment at industry level}

During or after the course of macro balances and adjustment process the following actions has been taken to satisfy sectoral balances.

Step 1. At the intersection of the Consumption column and the "Taxes less subsidies" row there is number 67,542 which represents taxes paid by consumers on their consumption. I distributed this item across 35 sectors in proportion to their shares in the Consumption column. Since the final demand (FD) block increased by this new tax column it was necessary to add one additional row by transposing this new taxes less subsidies column and inserting it into the value added block (VA). The rationale for this treatment is to maintain the balance between the income 
Özhan, M. (2016). Adapting WIOD tables to national IO Tables for Turkey. International Journal of Social

Sciences and Education Research, 2 (2), 327-337.

side and the expenditure side of GDP. Similarly, "Taxes less subsidies" on Government expenditure, Investment and Changes in Stocks are treated in the same way. That is the reason why there is another new row in the VA block, named "Taxes less subsidies on Government, Investment and Stocks".

Table 6. Shares of "Non-residents consumption on domestic territory" and "residents consumption abroad"

\begin{tabular}{|c|c|c|c|}
\hline & & $\begin{array}{r}\text { Non-residents } \\
\text { consumption }\end{array}$ & $\begin{array}{r}\text { Residents con- } \\
\text { sumption } \\
\text { abroad } \\
\end{array}$ \\
\hline 3 & Food, Beverages and Tobacco & 0.3464 & 0.3628 \\
\hline 4 & Textiles and Textile Products & 0.0929 & 0.0320 \\
\hline 5 & Leather, Leather and Footwear & 0.0732 & 0.0307 \\
\hline 7 & Pulp, Paper, Paper, Printing and Publishing & 0.0075 & 0.0099 \\
\hline 16 & Manufacturing, Nec; Recycling & 0.0880 & 0.0876 \\
\hline 19 & $\begin{array}{l}\text { Sale, Maintenance and Repair of Motor Vehicles and Motorcy- } \\
\text { cles; Retail Sale of Fuel }\end{array}$ & 0.0151 & 0.0197 \\
\hline 21 & $\begin{array}{l}\text { Retail Trade, Except of Motor Vehicles and Motorcycles; Repair } \\
\text { of Household Goods }\end{array}$ & 0.0151 & 0.0197 \\
\hline 22 & Hotels and Restaurants & 0.1649 & 0.2491 \\
\hline 23 & Inland Transport & 0.0389 & 0.0402 \\
\hline 24 & Water Transport & 0.0167 & 0.0172 \\
\hline 25 & Air Transport & 0.0444 & 0.0460 \\
\hline 26 & $\begin{array}{l}\text { Other Supporting and Auxiliary Transport Activities; Activities of } \\
\text { Travel Agencies }\end{array}$ & 0.0111 & 0.0115 \\
\hline 27 & Post and Telecommunications & 0.0151 & 0.0197 \\
\hline 28 & Financial Intermediation & 0.0075 & 0.0099 \\
\hline 30 & Renting of $\mathrm{M} \& \mathrm{Eq}$ and Other Business Activities & 0.0151 & 0.0197 \\
\hline 32 & Education & 0.0045 & 0.0098 \\
\hline 33 & Health and Social Work & 0.0262 & 0.0042 \\
\hline \multirow[t]{2}{*}{34} & Other Community, Social and Personal Services & 0.0174 & 0.0103 \\
\hline & & 1.0000 & 1.0000 \\
\hline
\end{tabular}

Source: Ozhan, Wang, Ozhan (2014).

Step 2. In the consumption column the sum of the two items $(-37,727)$ mentioned in Section 3 , namely, "Direct purchases abroad by residents", 8,846 , and "Purchases on the domestic territory by non-residents", $-46,573$ is distributed among a number of Consumption sectors. The name of these sectors and their shares are given in Table 6, column 3. The rationale for this allocation is that the same net figure $(-37,727)$ is contained in Consumption figure in GDP at macro level but excluded frpm sectoral origins.

Step 3. "Direct purchase abroad by residents", 8,846 , is also distributed across the column of Imports with shares shown in Table 6, column 4. Again the reason for this step is the same as in Step 2.

Step 4. "Purchases on the domestic territory by non-residents", 46,573, is distributed across the column of Exports with shares shown in Table 6, column 3. Table 6 is imported from an earlier study by the TURINA team (Ozhan, Wang, Ozhan, 2014). 
Özhan, M. (2016). Adapting WIOD tables to national IO Tables for Turkey. International Journal of Social Sciences and Education Research, 2 (2), 327-337.

Table 7. Final Balanced and Converted WIOD IOT Consistent with TurkStat NAS, 2011 (Millions of TL)

\begin{tabular}{|c|c|c|c|c|c|c|c|c|c|c|}
\hline $\begin{array}{l}\text { IOT } 2011 \\
\text { (Millions of } \\
\text { TL, } \\
\text { current prices }\end{array}$ & 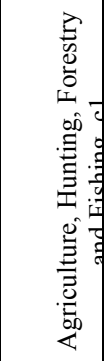 & 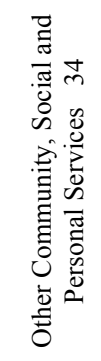 & 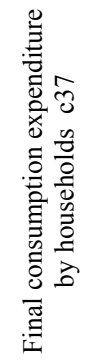 & 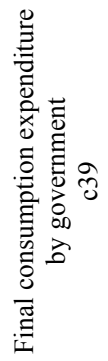 & 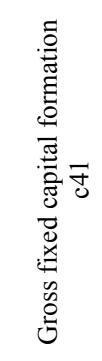 & 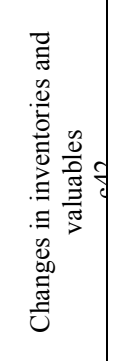 & 总莳 & $\begin{array}{l}\text { à } \\
\text { : }\end{array}$ & 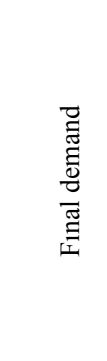 & $\begin{array}{l}\text { 言 } \\
\text { 言 } \\
\text { 嵒 } \\
\text {, }\end{array}$ \\
\hline $\begin{array}{l}\text { Agriculture, } \\
\text { Hunting, For- } \\
\text { estry and Fish- } \\
\text { ing c1 }\end{array}$ & 21,883 & 53 & 81.807 & 664 & 176 & 2,768 & 10,536 & 22,481 & 73,470 & 170,482 \\
\hline$\ldots$ & $\ldots$ & $\cdots$ & $\cdots$ & $\ldots$ & $\cdots$ & $\ldots$ & $\ldots$ & $\cdots$ & $\cdots$ & $\ldots$ \\
\hline $\begin{array}{l}\text { Other Commu- } \\
\text { nity, Social and } \\
\text { Personal Ser- } \\
\text { vices c34 }\end{array}$ & 70 & 5,247 & 21,313 & 6,649 & 278 & 10 & 1,495 & 1,311 & 28,434 & 41,143 \\
\hline $\begin{array}{c}\text { Total interme- } \\
\text { diate consump- } \\
\text { tion TOT r60 }\end{array}$ & 54,737 & 17,256 & 923,837 & 180,707 & 283,163 & 22,529 & 311,148 & 473,671 & $1,297,713$ & 0 \\
\hline $\begin{array}{l}\text { Taxes less sub- } \\
\text { sidies on prod- } \\
\text { ucts r99 }\end{array}$ & 6,247 & 907 & 0 & 0 & 0 & 0 & 0 & & & 83,206 \\
\hline $\begin{array}{l}\text { Taxes on pri- } \\
\text { vate consump- } \\
\text { tion }\end{array}$ & 5,844 & 1,568 & & & & & & & & 68,584 \\
\hline $\begin{array}{l}\text { Taxes on Gov- } \\
\text { ernment, In- } \\
\text { vestment, and } \\
\text { Stocks }\end{array}$ & 155 & 151 & & & & & & & & 13,345 \\
\hline $\begin{array}{l}\text { Cif/ fob adjust- } \\
\text { ments on ex- } \\
\text { ports r61 }\end{array}$ & 0 & 0 & 0 & 0 & 0 & 0 & 0 & & & 0 \\
\hline $\begin{array}{l}\text { Direct pur- } \\
\text { chases abroad } \\
\text { by residents } \\
\text { r62 }\end{array}$ & 0 & 0 & 0 & 0 & 0 & 0 & 0 & & & 0 \\
\hline $\begin{array}{l}\text { Purchases on } \\
\text { the domestic } \\
\text { territory by } \\
\text { non-residents } \\
\text { r63 }\end{array}$ & 0 & 0 & 0 & 0 & 0 & 0 & 0 & & & 0 \\
\hline $\begin{array}{l}\text { Value added at } \\
\text { basic prices r64 }\end{array}$ & $\begin{array}{c}103,49 \\
9\end{array}$ & 21,261 & 0 & 0 & 0 & 0 & 0 & & & $1,132,578$ \\
\hline $\begin{array}{l}\text { International } \\
\text { Transport Mar- } \\
\text { gins }\end{array}$ & 0 & 0 & 0 & 0 & 0 & 0 & 0 & & & 0 \\
\hline $\begin{array}{l}\text { Value added at } \\
\text { market prices }\end{array}$ & $\begin{array}{c}115,74 \\
5\end{array}$ & 23,887 & & & & & & & & $1,297,713$ \\
\hline $\begin{array}{l}\text { Output at basic } \\
\text { [market] prices }\end{array}$ & $\begin{array}{c}170,48 \\
2\end{array}$ & 41,143 & 923,837 & 180,707 & 283,163 & 22,529 & 311,148 & 473,671 & $1,297,713$ & 0 \\
\hline
\end{tabular}

The resulting balanced IOT of 2011 both at macro and sectoral level is given in Table 7. Finally, the names of all 35 IO sectors are given in Table A in the Appendix.

\section{Conclusions}

This paper summarizes the adjustment process of the Turkish IOTs constructed by the WIOD (World Input-Output Database) to local national accounts data. In particular, the 35-sector 2011 
Özhan, M. (2016). Adapting WIOD tables to national IO Tables for Turkey. International Journal of Social

Sciences and Education Research, 2 (2), 327-337.

IOT is balanced in a consistent way, on the premises that the TurkStat data is the best possible estimate at macro level. At sectoral level WIOD data are are highly reliable and accepted with greater confidence.

The main aim of the paper is to construct a series of balanced annual input-output tables (IOTs) from 1995 to 2011, which will be employed for the TURINA (Turkey's Interindustry Analysis model). The Turina is the Turkish version of multisectoral macroeconomic models adapted by INFORUM (Interindustry Forecasting at the University of Maryland) group. In general an Inforum model which we employ as the basic structure of TURINA requires one or more IO tables with three blocks, namely the interindustry flow matrix FM, the final demand block FD, and the value added block VA. However, the WIOD structure consists of six blocks. In addition to domestic interindustry and final demand flows it also contains detailed information for import flows into domestic industries and final demand categories.

The adjustment process is separated into two parts. The first is about macro balances and the second is about sectoral balances. At macro level three major steps are taken. The first step requires the addition of import rows to domestic rows in order to obtain the total intermediate and final demand figures. The second step requires the adjustment of the sum of the final demand categories to national account totals at aggregate level. The aggregate figures are taken from the TurkStat sources (www.tuik.gov.tr). The third step requires the adjustment of the value added totals to those coming from the national account income figures provided again by the TurkStat. At the initial stage of the macro adjustment process the GDP figure in TurkStat sources (TL1,297,713m) exceeded the WIOD figure (TL1,256,669m) by 3.2 percent. There were almost no differences between the two sources for the basic macro variables: Private final consumption (C), Government expenditures on goods and services $(\mathrm{G})$, and the gross fixed capital formation (I). However there were relatively big differences for the remaining macro variables: The changes in stocks (S), Exports (X), and Imports (M).

After arriving at balances at macro level, that is equating the WIOD values to those of the TurkStat data, there were only small differences at sectoral level between the two sources. The remaining imbalances at sectoral level were simply eliminated by adjusting only three variables: the changes in Stocks, total output, and value added.

\section{References}

Almon, C. (2011). The Craft of Economic Modelling - Part III Multisectoral Models, Department of Economics, University of Maryland.

Großmann, A., Hohmann, F., Wiebe, K. S. (2012). PortableDyme Documentation, Draft Version. Paper presented at XX Inforum World Conference, University of Florance, Italy.

Miller, R. E., Blair, Peter D. (2012). Input-Output Analysis Foundations and Extensions, Second Edition (Third Printing), Cambridge,

Ozhan, G. Yinchu W., Ozhan, M. (2014). "The Conversion and Adjustment of National IO Table Series from WIOD, the Case of Turkey", in Baranow, A., Suslov, V., Development of Macro and Interindustrial Methods of Economic Analysis, Siberian Branch of Academy of Sciences, Proceedings of XXI Inforum World Conference.

Stover, B., Wiebe, K. S., Lehr, U. (2013), Input-Output Modelling in the MENA Region - A Case Study for Morocco, GWS Discussion Paper 2012/3. 